\title{
Comparative study of the effect of bitter leaf extract and antibiotics (gentamycin and amoxicillin) on bacterial species isolated from wound
}

\author{
Oshilim A.O. \\ Department of Science Laboratory Technology, Delta State Polytechnic Ozoro, Delta State, Nigeria. \\ Email: tony4biz32@yahoo.com \\ Accepted 17 March, 2017
}

\begin{abstract}
Skin is the major organ of the human body which plays a vital role in maintaining health of human being. Certain diseases defined as infectious or communicable diseases are caused by pathogenic organisms. Some of the most common causative microorganisms related with infections include Staphylococcus aureus, Mycobacterium species, Lactobacillus species, Entrococcus species, Enterobacter aerogenes and Corynebacterium species. Most of the diseases spread by the bacteria which invade inside the body through skin. Bacterial infections on skin are the common ailment for generation of other disease in the body. Bacterial diseases are type of infectious diseases caused by pathogenic bacteria. These infections disturb the body immune system and causes inflammation, tissue damage and thus resulting in delayed wound healing process. The present study was undertaken to investigate the antibacterial effect of bitter leaf extract on pathogenic organisms isolated from wound. The antibacterial activities of bitter leaf extract ( $\mathrm{V}$, amygdalina) were determined against wound pathogens isolated from our study using Disc diffusion method for antibiotic sensitivity. The prevalence of the isolated wound pathogens were Corynebacterium species (80\%), Staphylococcus aureus (50\%), and Enterobacter aerogenes (30\%). All the extracts showed marked antibacterial activity but to varied zones of inhibition.
\end{abstract}

Keywords; bitter leaf, extract, antibiotics, wound, Gentamycin, Amoxicillin

\section{INTRODUCTION}

Microorganisms are the causative agent of wound infections, which is an important cause of morbidity in surgical patients (Orrett, 2002). The widespread use of antibiotics has resulted in increased bacterial resistance to existing drugs, a phenomenon which threatens public health (Kavase et al., 2001). The emergence and dissemination of antimicrobial resistance in bacteria has been well documented as a serious problem world wide (Cohen, 2000; Orrett, 2002 and Akinyemi et al., 2005).

Antimicrobial resistance results in increased illness, high cost of health maintenance and deaths. As a result, there is need for the discovery of new antimicrobial compounds probably acting through mechanisms different from those of existing drugs (Niccoli et al., 2001). Hence, the need to search for new antimicrobial agents from natural product of plant to combat the problems associated with drugs resistant strains of microorganisms (Nickel, 1995). The new epidemic of multi-drug resistance as an emergent pathogen resulting from our own mismanagement of antibiotics. Therefore, there is a need to look for substance from other sources with proven antimicrobial activity. Consequently this has led to the search for mere effective antimicrobial agent among materials of plant origin, with the aim of discovering potentially useful active ingredients that can serve as source and template for the synthesis of new antimicrobial drugs (Pretorious et al., 2003; Moreillion et al., 2005).

Herbal medicine is readily available in our diverse vegetation, cheap and carries the potential of introducing 
new templates into modern medicine (Okwori et al., 2007). Many plants synthesize substances that are useful to the maintenance of health in humans and other animals. Plant extract are continuously being sort for as effective and cheaper alternative sources of medication all over the world especially in the developing countries. Vernonia amygdalina commonly called bitter leaf (because of its bitter taste) is consumed either as a vegetable for cooking African soup or the aqueous extracts could be drank as fonics for the treatment of various illnesses (Abosi, and Raseroka 2003). The bitterness is suspected to be due to factors such as the presence of alkaloids, saponins, tannins and glycosides which have been shown by various authors to be present in bitter leaf (Butter and Bailey, 1973).

According to Huffman et al., 1993, the roots of $V$. amygdalina have been used for gingivitis and toothache due to its proven antimicrobial activity. The bacternial agents often incremianted in wound infections include Staphylococcus, Pseudomonas, Klebsiella, Proteus species and Escherichia coli as well as anaerobes such as Clostridium and Bacteroides species. The objective of the study is to evaluate the wound healing effects of Vernonia amygdalina on wound infection.

\section{MATERIALS AND METHODS}

\section{Sources}

The leaves of Vernonia amygdalina (Bitter leaf) were collected from uncultivated farmland located in Ozoro, southern part of Nigeria, the Department of Botany, Delta State University Abraka identified the plant samples.

\section{Sample Collection}

Fourteen wound samples was collected from different patients using swab stick and was properly labeled A (small wound sample) and B (big wound sample). The samples were properly centred at the place of collection. Both were transferred to the laboratory where analysis was carried out.

\section{Analysis}

\section{Isolation of Test Organisms}

The swab stick containing the sample was use to inoculate the plates of prepared nutrient agar, each sample to each plate and was incubated at $37^{\circ} \mathrm{c}$. Media prepared was according to the manufacturer instruction and then used for isolation of bacteria. Pure isolations where identified according to their morphological characteristics and reactions to bio chemical test.

\section{Bitter leaf extraction}

The sample leaves were cleansed, dried at room temperature for 2 weeks and grounded into powder. $250 \mathrm{~g}$ of the grinded powder (bitter leaf) was weighed and dispensed into 1 litre of water

\section{ANTIMICROBIAL SUSCEPTIBILITY TESTING}

When a pathogen was isolated and idetified, antimicrobial sensitivity test was done (Bowler et al., 2001). Agar plates were inoculated with the bacteria growth. $10 \mathrm{~mm}$ well was bore in the agar plates, 0.1 and 0.2 of the bitter leaves extracts was impregnated into the well of the agar plates containing the organism, other antibiotics like Gentamycin and Amoxillcin was also use as control. After which the plates were kept at $23^{\circ} \mathrm{C}$ for 48 hours. The inhibitory zone of the test organisms was taken as the minimum inhibitory zone and measured in 16 millimetre $(\mathrm{mm})$.

\section{RESULTS}

The organisms isolated from the wound samples are Corynebacterium species, Enterobacter aerogenes, Enterococcus species, Mycobacterium species and Staphylococcus aureus. The bacterial isolates has the ability to utilize sugar as their substrate as shows in table 1. Table 2 shows the morphological and biochemical characteristics of isolated bacteria of wound swab. Table 3 shows bacterial isolates, number of occurrence of isolate identified in different wound swab samples and heterotrophic plate count. Table 4 Mean Heterotrophic plate counts. (CFU/ml count) for various wound swab samples were kept at $23^{\circ} \mathrm{C}$ for 48 hours. The inhibitory zone of the test organisms was taken and measured in millimeter ( $\mathrm{mm}$ ) (Table 5).

\section{DISCUSSION}

Wound infection is a major cause of morbidity and mortality and a major source of worry to both the patients, doctors, hospitals and the community as a whole. Increasing multidrug resistance of pathogens has renewed the research for alternative compounds for the treatment of infectious diseases. The antibacterial activity of bitter leaf extract against some bacterial species isolated from wounds were investigated. The result of this study indicated that the Gram negative bacilli were more common in infected wounds than the Gram positive bacteria, although the prevalence rate of Staphylococcus aureus $80 \%$ was higher when compared with that of the gram negative (48\%). This finding is in line with the ones earlier reported by Sule et al., 2001. 
Table 1: Cultural, Morphological and Biochemical Characteristics of Bacteria Isolates

\begin{tabular}{|c|c|c|c|c|c|c|c|c|c|c|}
\hline Isolates & Gram stain & 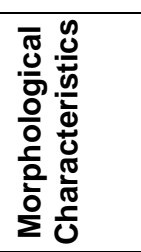 & 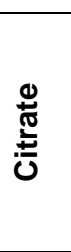 & 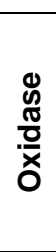 & 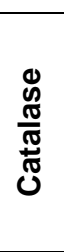 & $\begin{array}{l}\frac{0}{0} \\
\text { 을 }\end{array}$ & 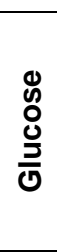 & 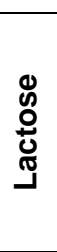 & $\begin{array}{l}\text { N̦ } \\
\text { I }\end{array}$ & 趂 \\
\hline Mycobacterium species & (Acid fast bacilli) & Rods & + & - & + & - & + & + & - & - \\
\hline Enterococcus species & GPB & Rods & + & - & + & - & + & + & - & - \\
\hline Corynebacterium species & GPB & Rods & - & - & + & - & + & - & - & + \\
\hline Staphylococcus aureus & GPC & Cocci & - & - & + & + & + & + & - & + \\
\hline Enterobacter aerogenes & GNS & Rods & + & - & + & - & + & + & - & - \\
\hline Lactobacillus species & GPB & Rods & - & - & + & - & + & + & + & - \\
\hline
\end{tabular}

Table Key: += positive, - = Negative, GPB = Gram positive Bacillus, GNB = Gram Negative Bacillus, GPC = Gram positive cocci

Table 2: Shows bacteria isolates, number of occurrence and percentage of occurrence

\begin{tabular}{lccc}
\hline Sample & Bacterial Isolates & Number of occurrence per samples & Percentage (\%) of occurence \\
\hline A & Corynebacterium species & 4 & 80.00 \\
& Mycobacterium species & 1 & 20.00 \\
& Enterobacter aerogenes & 3 & 30.00 \\
& Enterococcus species & 1 & 10.00 \\
B & Lactabacillus species & 1 & 10.00 \\
& Staphylococcus aureus & 5 & 50.00 \\
\hline
\end{tabular}

Table 3: Heterotrophic plate counts

\begin{tabular}{lccc}
\hline Sample & Bacteria isolates & CFU/ML & CFU/ML in Standard form \\
\hline A & Corynebacterium, species & 52 & $5.2 \times 10^{1}$ \\
& Corynebacterium species & 80 & $8.0 \times 10^{1}$ \\
& Corynebacterium species & 36 & $3.6 \times 10^{1}$ \\
& Corynebacterium species & 40 & $4.6 \times 10^{1}$ \\
Mycobacterium species & 60 & $6.0 \times 10^{1}$ \\
& Enterobacter aerogenes & 72 & $7.2 \times 10^{1}$ \\
Enterobacter aerogenes & 64 & $6.4 \times 10^{1}$ \\
Enterobacter aerogenes & 92 & $9.2 \times 10^{1}$ \\
Enterococcus species & 56 & $5.6 \times 10^{1}$ \\
& Lactobacillus species & 56 & $5.6 \times 10^{1}$ \\
& Staphylococcus aureus & $4.8 \times 10^{1}$ \\
Staphylococcus aureus & 48 & $6.0 \times 10^{1}$ \\
Staphylococcus aureus & 60 & $8.0 \times 10^{1}$ \\
Staphylococcus aureus & 80 & $7.6 \times 10^{1}$ \\
Staphylococcus aureus & 76 & $6.8 \times 10^{1}$ \\
\hline
\end{tabular}

Table 4: Mean Heterotrophic plate counts. (CFU/ml count)

\begin{tabular}{ll}
\hline Samples & Means of CFU/ML \\
\hline A & 53.60 \\
B & 67.20 \\
\hline
\end{tabular}


Table 5: The Zone of inhibition of different concentration, Gentamycin and Amoxicillin different bacterial isolates.

\begin{tabular}{lcccc}
\hline Isolates & Bitter leaves extracts $\mathbf{( 0 . 1} \mathbf{~ m l})$ & Bitter leaves extract $\mathbf{( 0 . 2}$ ml) & GEN & AM \\
\hline Corynebacterium species & 25 & 30 & 22 & 11 \\
Enterobacter aerogenes & 11 & 14 & 16 & 25 \\
Enterococcus species & 11 & 15 & 24 & 0 \\
Lactobacillus species & 0 & 0 & 0 & 0 \\
Mycobacterium species & 12 & 14 & 19 & 12 \\
Staphylococcus aureus & 17 & 20 & 13 & 25 \\
\hline
\end{tabular}

KEY $0=$ RESISTANT,GEN=GENTAMYCIN,AM=AMOXACILLIN 0=RESISTANCE

According to Ogundare et al., (2006) the presence of saponins, flavonoids, tan-nins and anthraquinones in bitter leave was found to have very potent antibacterial effect. Secondary metabolites of plants such as tannins, reducing sugar and saponins and all other active principles of plants have been shown to be responsible for the antimicrobial activities shown by this extract. For instance, the sensitivity of Corynebacterium species to bitter leaf may be due to the presence of active saponins and essential oils Desta (1993). The study also showed that the isolate of Corynebacterium species was found to be the most susceptible to bitter leaf with an inhibition zone diameter range of $25 \mathrm{~mm}$ and $30 \mathrm{~mm}$ at $0.1 \mathrm{ml}$ and $0.2 \mathrm{ml}$ concentrations followed by Staphylococcus auerus with an inhibition zone diameter range of $17 \mathrm{~mm}$ and $20 \mathrm{~mm}$ when compared with inhibition zone diameter range of $22 \mathrm{~mm}$ and $11 \mathrm{~mm}$ for Gentamycin and amoxicillin respectively. The susceptibility of Corynebacterium species to bitter leave extract agreed with the findings of Arekemase et al., 2013 that demonstrated the antimicrobial activity of some medicinal plants against bacteria by using the extract of bitter leave extract as one of the samples. The lactobacillus species is resistance to bitter leave extract at both concentrations of $0.1 \mathrm{ml}$ and $0.2 \mathrm{ml}$ and it was also observed in Gentamycin and Amoxicilin .Since all the organisms were affected in one way or the other by exposure to different concentrations, it is very possible that at much high concentrations and observable time limit, there could be bactericidal effect on the organisms.

\section{Conclusion}

The phytochemical constituent of bitter leave has shown to be responsible for the antibacterial activities shown by its extracts. This leaf extracts could be used as broad spectrum antibiotics in the treatment of wound infections since it has antibacterial effects on these pathogens isolated.

\section{Reference}

Abosi AO, Raseroka $\mathrm{BH}$ (2003). In vivo antimalarial activity of vernonia ammygdalina Br. j. of Biome D. Sec, 60 (20): 89-91.
Akinyemi KO, Oladapo O, Okwara CE, Ibe CC, Fasure KA (2005). Screening of crude extracts of six medical plants used in South-west, Nigeria. Unorthodox Medicine Antimethicilin Resistant Staphylococcus aureus activity. BMC Complementary and Alternative Medicine 5(6):17.

Arekemase MO, Oyeyiola GP, Balogun KI (2013). Assessment of vernonia amygdalina on some selected pathogenic microorganisms from university of Ilorin teaching hospital. $\mathrm{J}$ of microbiol, biotechnol and food sci 2(5) 2360-2365.

Butter GW, Bailey RW (1973). Chemistry and biochemistry of Herbage Vol. 1 Academic Press, London. 1x639.

Cohen ML (2000). Changing patterns of infectious disease. Nature. 406:762-767.

Desta B (1993). Ethiopian traditional herbs Part II. Antimicrobial activity of 63 medicinal plants. Journal of Ethnopharmacology 39: 263-276.

Huffman MA, Gotoh S, Izutsu D, Koshimiz K, Kalunde MS (1993). Further observation on the use of the medicinal plant, vernonia amygdalina (Del) by a wild Chimpanzee, Its possible effect on parasites load, and its phytochemistry. Afr. Study Monger. 14(4):27240.

Kavase M, Motohashi N, Sakagami H, Kanamoto T, Nakashima T, Ferneczy L, Wolfard K, Miskoci C, Molnar J (2001). Antimicrobial activity of trifluoromethyl ketones and their synergism with promethazine. Int. J. Antimicrobial Agents.18(2):161-165

Moreillion P, Que YA, Glauser MP (2005). Staphylococcus aureus (including staphylococcal toxic shock). In Principles and Practice of Infectious Diseases (Eds) Mandell, G.L, Benneth, J.E, Dolin, R, Churchill Living Stone Pennsylvania $6^{\text {th }}$ ed. (2): 2333-2339.

Niccoli DL, Tarsi L, Thomas RJ (2001). The renewed challenges of antibacterial chemotherapy. Chem. Commun. 42:2333-2342.

Nickel LG (1995). Antimicrobial activity of Tanzanian traditional medicinal plants. The United Republic of Tanzania. Dar ES Salam University Press. Ministry of Health-Tanzania. 1991:391.

Ogundare AO, Adetuyi FC, Akinyosoye FA (2006). Antimicrobial Activities of Vernonia tenoriana, African. J of Biotechnol, 5(18):16631668.

Okwori AE, Pina GO, Okeke IO, Adetunyi JA(2007). Antibacterial activities of ageratum conyzoides extracts on selected bacterial pathogens. The intl $\mathrm{J}$ of Microbiol 4(1)1-16.

Orrett $F A(2002)$. Nosocomial infections in a intensive care and in a private hospital. West Indian Medicxal Journal 51:21-24.

Pretonous JC, Magama S, Zietsman DC (2003). Growth inhibition of plant pathogenic bacteria and fungi by Extracts from Selected South African Plant Species. South African J of Botany 20:188-192.

Sule AM, Olusanya O (2000). In-vitro antibacterial activities of fluoroquinolones compared with common antimicrobial agents against clinical bacterial isolates: from parts of south western Nigeria. Nigeria Quarterly J of Hosp Med 10 (1). 